\title{
Pengaruh Model CLIS terhadap Hasil Belajar IPA Kelas V SD di Gugus X Kecamatan Kintamani
}

\author{
I Gede Surya ${ }^{1}$, Nyoman Dantes ${ }^{2}$ \\ ${ }^{1}$ Jurusan Pendidikan Guru Sekolah Dasar, FIP \\ ${ }^{2}$ Prodi Pendidikan Dasar Pasca Sarjana \\ Universitas Pendidikan Ganesha \\ Singaraja, Indonesia \\ e-mail : they.surya12@gmail.com¹, dantes@undiksha.ac.id²,
}

\begin{abstract}
Abstrak
Penelitian ini bertujuan untuk mengetahui: (1) pengaruh secara efektif implementasi model pembeljaran Children Learning In Science (CLIS) terhadap hasil belajar IPA siswa dan (2) perbedaan hasil belajar IPA siswa yang mrngikuti pembelajaran dengan enerapkan model pembelajaran Children Learning In Science (CLIS) dan siswa yang mengikuti pembelajaran dengan menerapkan model pembelajaran konvensional pada siswa kelas V SD di Gugus X Kecamatan Kintamani. Jenis penelitian ini adalah penelitian eksperimen semu dengan desain non equivalent post - test only control group design. Populasi penelitian ini adalah seluruh siswa kelas V SD di Gugus X Kecamatan Kintamani yang berjumlah 97 orang. Pengambilan sampel menggunakan teknik random sampling, sehingga diperoleh sampel yaitu siswa kelas $\mathrm{V}$ SDN Sekardadi berjumlah 25 orang sebagai kelompok eksperimen dan siswa kelas V SDN 1Terunyan berjumlah 20 orang sebagai kelompok kontrol. Data hasil belajar IPA siswa dikumpulkan dengan menggunakan metode tes, yaitu tes objektif. Data yang dikumpulkan dianalisis dengan uji-t dan ANAVA-A.Penelitian ini memperoleh hasil bahwa: (1) terdapat pengaruh secara efektif implementasi model pembelajaran Children Learning In Science (CLIS) terhadap hasil belajar IPA dengan menunjukkan efektivitas tinggi hasil ES = 1,84 dan (2) terdapat perbedaan hasil belajar IPA siswa yang mengikuti pembelajaran dengan menerapkan model Children Learning In Science (CLIS) dan siswa yang mengikuti pembelajaran dengan menerapkan model konvensional dengan $F_{\text {hitung }}=25,08>F_{\text {tabel }}=4,0566$. Dapat disimpulkan bahwa terdapat pengaruh secara signifikan model pembelajaran Children Learning In Science (CLIS) terhadap hasil belajar IPA siswa kelas V SD di Gugus X Kecamatan Kintamani.
\end{abstract}

Kata Kunci: model CLIS, hasil belajar IPA

\begin{abstract}
This study aims to determine the effect of effective implementation of learning model Learning Children's Learning (CLIS) on the students' learning outcomes and the difference of science learning outcomes between students who are taught by the Learning Learning Science model (CLIS) and students who are taught by conventional learning model on $V$ grade elementary school students in Gugus X Kecamatan Kintamani Bangli District Lesson Year 2017/2018. This research type is quasi experiment research with non equivalent design post test only control group design. The population of this research is all students of class $V$ in Gugus $X$ Kecamatan Kintamani which amounted to 97 people. Sampling using simple random sampling technique, so that the result of sample drawing in research that is student of class $V$ SDN Sekardadi amounted to 25 people as experiment group and class $V$ student SDN 1 Terunyan amounted to 20 people as control group. students' science learning outcomes are collected using test methods, ie objective tests. The data collected were analyzed using t-test analysis and ANAVA-A. The study found that: (1) there is an effect of effectively implementing the Learning Learning Science model (CLIS) on the science learning outcomes by demonstrating the high effectiveness of the $E S=1,84$; (2) there is difference of science learning outcomes between students who follow learning model of Children Learning In Science (CLIS) with students who follow learning with conventional model with Sig. 4.056<25,08. It can be concluded that the learning model of Children Learning In Science (CLIS) is effective and can improve science learning outcomes of grade V SD students in Gugus X Kecamatan Kintamani.
\end{abstract}

Keywords: CLIS model, science learning outcomes 


\title{
1. Pendahuluan
}

Pendidikan merupakan suatu proses yang berlangsung secara berkelanjutan yang dapat membangkitkan keaktifan dan potensi siswa yang dilakukan secara sadar. Hamalik (2012:3) menjelaskan bahwa:

\begin{abstract}
"pendidikan adalah suatu proses dalam rangka mempengaruhi peserta didik supaya mampu menyesuaikan diri sebaik mungkin dengan lingkungannya, dan dengan demikian akan menimbulkan perubahan dalam dirinya yang memungkinkannya untuk berfungsi secara adekwat dalam kehidupan masyarakat".
\end{abstract}

Tujuan pendidikan menurut Undang-Undang No 20 tahun 2003 tentang Sistem Pendidikan Nasional, Pasal 3 adalah Mengembangkan potensi peserta didik agar menjadi manusia yang beriman dan bertakwa kepada Tuhan Yang Maha Esa, berhaklak mulia, sehat berilmu, cakap, kreatif, mandiri, dan menjadi warga negara yang demokratis serta bertangung jawab. Jadi pendidikan merupakan suatu aspek kehidupan yang sangat mendasar sebagai pembangunan bangsa. Pendidikan sekolah dasar merupakan jenjang pendidikan yang paling mendasar dan menjadi pondasi dalam mengembangkan aspek pengetahuan yang dimiliki siswa untuk memperoleh pengetahuan melalui proses pembelajaran.

Kurikulum merupakan syarat mutlak bagi pelaksanaan pendidikan di sekolah. Setiap pelaksanaan pendidikan diarahkan pada sebuah pencapaian-pencapaian tujuan yang telah ditetapkan. Lasmawan (2013:4)menyatakan bahwa:

"kurikulum dimaknai sebagai pengalaman belajar yang direncanakan sebagai dasar dan acuan dalam merencanakan, melaksanakan, mengevaluasi dan mengembangkan serta pelaksanaan dari kurikulum tersebut untuk mampu mentransformasi materi pendidikan menjadi pengalaman belajar bagi peserta didik".

Kurikulum terdiri dari kumpulan mata pelajaran diantaranya IPA, IPS, Bahasa Indonesia, danlain sebagainya. Susanto (2013:167) menjelaskan bahwa"sains atau IPA adalah usaha manusia dalam memahami alam semesta melalui pengamatan yang tepat pada sasaran, serta menggunakan prosedur, dan dijelaskan dengan penalaran sehingga mendapatkan suatu kesimpulan". Jadi proses pembelajaran IPA sangat penting diterapkan untuk menambah pengetahuan siswa di sekolah dasar dan harus dilaksanakans esuai dengan strategi yang tepat agar siswa mudah memahaminya. Karena pembelajaran IPA di sekolah dasar melibatkan anakanak, maka proses pembelajaran harus dilaksanakan semenarik mungkin untuk memancing keaktifan serta minat belajar siswa dan guru juga harus tetap membimbing siswa untuk tetap disiplin.

Mata pelajaran IPA di sekolah dasar dianggap susah karena kajian teorinya yang luas sehingga di sekolah dasar banyak masalah-masalah yang ditemui oleh guru dan siswa dalam proses pembelajaran IPA. Seperti masalah-masalah yang ditemukan di Gugus X Kecamatan Kintamani Kabupaten Bangli yang terdiri dari 6 sekolah dasar yaitu, SDN 1 Terunyan, SDN 3 Terunyan, SDN 2 Abang Batu Dinding, SDN 1 Buahan, SDN Kedisan, dan SDN Sekardadi. Karena SDN Kedisan sudah menerapkan Kurikulum 2013 maka tidak dicantumkan dalam penelitian ini. Dari hasil observasi yang dilakukan dengan guru-guru kelas $\mathrm{V}$ yang ada di masing-masing sekolah ditemukan beberapa masalah yaitu, (1) kurangnya pemahaman siswa mengenai konsep pembelajaran IPA, (2) penggunaan model pembelajaran yang tidak relevan,(3) siswa masih kurang aktif dalam mengikuti proses pembelajaran, (4) proses pembelajaran masih berpusat pada guru, dan (5) nilai rata-rata hasil belajar IPA siswa masih tergolong rendah.

Dari setiap masalah-masalah yang ditemukan tentunya pasti ada solusi yang bisa digunakan dalam memecahkan atau meringankan masalah tersebut. Untuk mengatasi masalah yang telah ditemukan di Gugus X Kecamatan Kintamani maka di temukan solusi yaitu dengan menerapkan model pembelajaran Children Learning In Science (CLIS). Menurut Ismai (2017) Model pembelajaran CLIS adalah kerangka berpikir untuk menciptakan lingkungan yang memungkinkan terjadinya kegiatan belajar mengajar yang melibatkan siswa dalam kegiatan pengamatan dan percobaan dengan menggunakan Lembar Kerja Siswa (LKS). 
Menurut Nurani (2017) model pembelajaran Children Learning In Science mempunyai tujuan agar pembelajaran dapat bertahan lama karena pembelajaran CLIS memuat tahap-tahap kegiatan siswa dalam mem-pelajari konsep yang diajarkan. Menurut Wardani (2017) model pembelajaran CLIS adalah sebuah model pembelajaran yang mengutamakan kreatifitas siswa dan memberikan kesempatan kepada siswa untuk mengungkapkan ide atau gagasan yang dimilikinya secara menyeluruh, dan dapat mengembangkan gagasannya melalui percobaan sedangkan guru hanya sebagai fasilitator dan sebagai pembimbing. Wardana (2013) menyatakan bahwa "pembelajaran menggunakan model pembelajaran Children Learning In Science (CLIS) akan memberikan kesempatan kepada siswa untuk berperan aktif dalam kegiatan belajar yang dimulai dari tahap awal yaitu orientasi, pemunculan gagasan, penyusunan ulang gagasan, penerapan gagasan, dan pemantapan gagasan".

Samatowa (2010:74) Model pembelajaran Children Learning In Science (CLIS) terdiri dari lima tahapan, yaitu sebagai berikut.

1. Orientasi

Merupakan upaya untuk memusatkan perhatian siswa, misalnya dengan menyebutkan dan mempertontonkan suatu peristiwa yang terjadi dalam kehidupan sehari-hari, yang berkaitan dengan topik yang dipelajari.

2. Pemunculan Gagasan

Merupakan upaya untuk memunculkan konsepsi awal siswa. Misalnya dengan cara meminta siswa menuliskan apa saja yang telah diketahui tentang topik pembicaraan, atau dengan menjawab beberapa pertanyaan uraian terbuka. Bagi guru tahapan ini merupakan upaya eksplorasi pengetahuan siswa.Oleh karena itu, tahapan ini juga dilakukan melalui wawancara informal.

3. Penyusunan Ulang Gagasan

Tahapan ini merupakan upaya untuk memperjelas dan mengungkapkan gagasan awal siswa tentang suatu topik secara umum, misalnya dengan cara mendiskusikan jawaban siswa pada langkah kedua (pemunculan gagasan) dalam kelompok kecil, kemudian salah satu perwakilan kelompok menyampaikan hasil diskusi tersebut pada seluruh kelas. Pada tahap pembuktian ke situasi konflik siswa diberi kesempatan untuk mencari pengertian ilmiah yang sedang dipelajari di dalam buku teks.Selanjutnya siswa mencari beberapa perbedaan antara konsepsi awal mereka dengan konsepsi ilmiahyang ada dalam buku teks atau hasil pengamatan terhadap kegiatan yang dilakukan.Siswa diberi kesempatan untuk melakukan percobaan dengan observasi, kemudian mendiskusikannya dengan kelompoknya.

4. Penerapan Gagasan

Pada tahap ini siswa diminta menjawab pertanyaan yang disusun untuk menerapkan konsep ilmiah yang telah dikembangkan siswa melalui percobaan/observasi ke dalam situasi baru.

5. Pemantapan Gagasan

Konsepsi yang telah diperoleh siswa perlu diberi umpan balik oleh guru untuk memperkuat konsep ilmiah tersebut. Dengan demikian diharapkan siswa yang konsepsi awaknya tidak konsisten dengan konsep ilmiah sadar akan mengubah konsepsi awalnya menjadi konsep ilmiah.

Dengan menerapkan model pembelajaran Children Learning In Science (CLIS) akan memberikan kesempatan kepada siswa untuk bebas berpendapat dan bisa selalu berinteraksi dngan lingkungan, karena proses pembelajaran berpusat pada siswa sehingga siswa bisa aktif dan kreatif dalam mengikuti pembelajaran.

Penelitian ini juga didukung oleh penelitian yang dilakukan oleh Wyn. Adi Wardana (2013) yang dalam hasil penelitiannya menunjukan bahwa sebagian besar skor hasil belajar IPA pada siswa yang dibelajarkan dengan model pembelajaran konvensional cenderung lenih rendah di bandingkan dengan sjor hasil belajar IPA siswa yang dibelajarkan dengan model pembelajaran Children Learning In Science.

Berdasarkan uraian di atas, maka dilakukan penelitian yang berjudul Pengaruh Model Pembelajaran Children Learning In Science (CLIS) Terhadap Hasil Belajar IPA Siswa Kelas V SD di Gugus X Kecamatan Kinramani Kabupaten Bangli Tahun Pelajaran 2017/2018.

\section{Metode}

Penelitian ini merupakan penelitian eksperimen semu (quasi eksperiment). Karena tidak semua variabel yang muncul dan kondisi eksperimen dapat diatur dan dikontrol secara ketat. Penelitian ini menggunakan rancangan non equivalent post-test only control group design. Dalam penelitian ini dibandingkan menggunakan model pembelajaran Children Learning In 
Science (CLIS) dengan tidak menggunakan model pembelajaran Children Learning In Science (CLIS) terhadap hasil belajar siswa dalam pelajaran IPA.Populasi dalam penelitian ini adalah seluruh siswa kelas V SD di Gugus X Kecamatan Kintamani Kabupaten Bangli tahun pelajaran 2017/2018 yang terdiri atas 5 (lima) sekolah dasar yaitu: SDN 1 Terunyan, SDN 3 Terunyan, SDN 2 Abang Batu Dinding, SDN 1 Buahan, dan SDN Sekardadi. Distribusi jumlah siswa kelas V SD Gugus X Kecamatan Kintamani Kabupaten Bangli tahun pelajaran 2017/2018. Sebelum menentukan sampel terlebih dahulu dilakukan uji kesetaraan dengan menggunakan uji ANAVAA satu jalur dengan bantuan Microsoft Excel 2017 untuk mengetahui kemampuan akademik yang dimiliki siswa kelas V SD di Gugus X Kecamatan Kintamani setara atau tidak. Pemilihan sampel yang digunakan sebagai kelas eksperimen dan kelas control dilakukan dengan teknik random sampling. Berdasarkan pengertian teknik random sampling, maka dilakukan dua kali pengundian. Pengundian yang dilakukan Terhadap 5 SD dengan tehnik acak mendapatkan hasil bahwa kelas V SDN Sekardadi menjadi kelas eksperimen yang berjumlah 25 siswa dan Kelas V SDN 1 Terunyan sebagai kelas kontrol yang berjumlah 20 siswa.

Data yang dikumpulkan pada penelitian ini adalah data hasil belajar IPA siswa kelas V SD. Untuk mengumpulkan data tersebut diperlukan suatu metode yang tepat. Pada penelitian ini menggunakan metode pengumpulan data, yaitu menggunakan metode tes pilihan ganda yang berjumlah 40 soal dengan empat alternative pilihan jawaban a, b, c, dan d untuk memudahkan siswa dalam menjawab soal. Sebelum dignakan tes tersebut sudah diuji cobakan dilapangan untuk menguji validitas, reliabiltas, daya beda, dan tingkat kesukaran tes.

Dalam penelitian ini menggunakan metode analisis uji $t$ dan analisis Varian (ANAVA-A). Uji t digunakan untuk mengetahui keefektifan model pembelajaran. Analisis varian (ANAVA-A) yang digunakan untuk mengetahui perbedaan hasil belajar IPA.Dalam penelitian ini analisis deskriptif dilakukan untuk mengetahui tinggi rendahnya kualitas hasil belajar siswa, baik yang dibebelajarkan dengan menggunakan model pembelajaran Children Learning In Science (CLIS) maupun yang tidak menggunakan model pembelajaran Children Learning In Science (CLIS).Untuk menentukan tinggi rendahnya kualitas variabel-variabel tersebut, skor rata-rata (mean) tiap-tiap variabel dikonversikan dengan menggunakan kriteria rata-rata ideal $\left(\mathrm{M}_{\mathrm{i}}\right)$ dan standar deviasi ideal $\left(\mathrm{SD}_{\mathrm{i}}\right)$.

Sebelum melakukan uji hipotesis terlebih dahulu dilakukan uji prasyarat yaitu: (1) Uji normalitas, Untuk menguji normalitas hasil belajar IPA digunakanlah rumus Chi-Kuadrat:

$$
\mathbf{x}^{2}=\Sigma \frac{\left(f_{0}-f_{e}\right)^{2}}{f_{e}}
$$

(Koyan, 2012)

Keterangan:

$$
\begin{aligned}
& f_{0}=\text { Frekuensi Observasi } \\
& f_{e}=\text { Frekuensi Harapan }
\end{aligned}
$$

Apabila $x^{2}$ hitung $<x_{\text {tabel }}^{2}$, maka sampel berasal dari populasi yang berdistribusi normal dan (2) uji homogenitas, Uji homogenitas untuk persyaratan analisis regresi menggunakan teknik yang sama dengan uji homogenitas untuk persyaratan uji perbedaan. Perbedaannya terletak pada cara pengelompokan data variabel terikat. Jika pada uji perbedaan, pengelompokan data variabel terikat didasarkan pada kelompok sampel, maka pada uji homogenitas pada uji regresi, pengelompokan data variabel terikat dilakukan berdasarkan data variabel bebas (lihat pada analisis varians tuna cocok, untuk menganalisis linearitas regresi). Untuk menguji homogenitas varians untuk kedua kelompok digunakan uji $F$.

$$
\mathrm{F} \text { hit }=\frac{\text { Variansterbesar }}{\text { Variansterkecil }}
$$

Apabila $\mathrm{F}$ hitung $\geq \mathrm{F}$ tabel maka kedua populasi memiliki varians yang berbeda (tidak homogen), Jika $\mathrm{F}$ hitung $<\mathrm{F}$ tabel maka kedua populasi memiliki varians yang homogen. Pengujian dilakukan pada taraf signifikansi $5 \%$ dengan derajat kebebasan untuk pembilang $\mathrm{n} 1-1$, derajat kebebasan untuk penyebut $\mathrm{n} 2-1$. 


\section{Hasil dan Pembahasan}

Penelitian ini dirancang dengan menggunakan jenis penelitian eksperimen semu (quasi experiment). Tempat penelitian ini dilakukan di SD Gugus X Kecamatan Kintamani Kabupaten Bangli yang dilakanakan pada rentang waktu semester II (genap) pada tahun pelajaran 2017/2018. Pelaksanaan pembelajaran pada penelitian ini dilakukan pada hari senin 19 maret 2018 sampai dengan selasa, 10 April 2018. RPP eksperimen dan kontrol. Pelaksanaan Post test pada kelas eksperimen dan kelas kontrol dilakukan pada selasa, 17 April 2018. Intstrumen yang digunakan dalam pengumpulan data penelitian ini adalah lembar soal objektif yang terdiri dari 30 soal. Data yang dikumpulkan dalam penelitian ini adalah skor hasil belajar IPA pada ranah kognitif yang diperoleh dari posttest setelah mengadakan 7 kali pertemuan pada masingmasing kelompok siswa yang dibelajarkan dengan menggunakan model pembelajaran Children Learning In Science (CLIS) pada kelompok eksperimen dan pembelajaran konvensional pada kelompok kontrol. Rekapitulasi perhitungan data hasil penelitian tentang hasil belajar IPA siswa dapat dilihat pada Tabel1.

Tabel 1. Rekapitulasi Hasil Perhitungan Skor Hasil Belajar IPA

\begin{tabular}{lccc}
\hline \multicolumn{1}{c}{ Data } & \multicolumn{2}{c}{ Hasil Belajar IPA } & Total \\
\cline { 2 - 3 } \multicolumn{1}{c}{ Statistik } & $\begin{array}{c}\text { Kelompok } \\
\text { Eksperimen }\end{array}$ & $\begin{array}{c}\text { Kelompok } \\
\text { Kontrol }\end{array}$ & 132,28 \\
Mean & 74,88 & 57,4 & 129,56 \\
Median & 75,06 & 54,5 & 132,64 \\
Modus & 79,64 & 53 & 254,47 \\
Varians & 164,60 & 89,87 & 22,31 \\
Standar Deviasi & 12,83 & 9,48 & 83 \\
Skor minimum & 43 & 40 & 176 \\
Skor maxsimum & 93 & 83 & 93 \\
Rentangan & 50 & 43 & \\
\hline
\end{tabular}

Berdasarkan Tabel di atas hasil belajar kelompok eksperimen dapat dideskripsikan sebagai berikut: mean $(M),=74,88$, median $(M d)=75,06$, modus $(M o)=79,64$. Sedangkan hasil belajar di kolompok kontrol dapat diperoleh hasil mean $(\mathrm{M}),=57,4$, median $(\mathrm{Md})=54,5$, modus $(\mathrm{Mo})=53$. Setelah itu dilakukan uji prasyarat yaitu uji normalitas dan uji homogenitas. Berdasarkan hasil perhitungan uji normoalitas dengan menggunakan rumus chi-kuadrat yang memperoleh hasil yang ditunjukkan pada Tabel 2 sebagai berikut.

Tabel 2. Ringkasan Hasil Uji Normalitas Sebaran Data Hasil Belajar IPA

\begin{tabular}{clccc}
\hline No & Kelompok Data Hasil Belajar & $\chi^{2}$ hutung & $\chi^{2}$ tabel & Status \\
\hline 1 & Eksperimen & 6,246 & 7,815 & Normal \\
2 & Kontrol & 2,892 & 5,591 & Normal \\
\hline
\end{tabular}

Dari Tabel di atas diperoleh $\chi^{2}$ hitung hasil belajar IPA siswa kelompok eksperimen adalah 6,246 dan $X_{\text {tabel }}^{2}$ dengan taraf signifikansi $5 \%$ dan $\mathrm{db}=.6-2-1=3$ adalah 7,815 . Hal ini berarti, $X^{2}$ hitung hasil belajar IPA siswa kelompok eksperimen lebih kecil dari $X_{\text {tabel }}^{2}\left(X_{\text {hitung }}^{2}<X_{\text {tabel }}^{2}\right)$ sehingga data hasil belajar IPA siswa kelompok eksperimen berdistribusi normal. Sedangkan, $X^{2}$ hitung hasil belajar IPA siswa kelompok kontrol adalah 2,892.dan $X_{\text {tabel }}^{2}$ dengan taraf signifikansi $5 \%$ dan $\mathrm{db}=5-2-1=2$ adalah 5,591 . Hal ini berarti, $X^{2}$ hitung hasil post-test kelompok kontrol lebih kecil dari $X^{2}$ tabel $\left(X^{2}\right.$ hitung $<X^{2}$ tabel) sehingga data hasil belajar IPA siswa kelompok kontrol berdistribusi normal. Setelah melakukan uji normalitas selanjutnya dilakukan uji homogenitas dan memperoleh hasil yang tertera pada Tabel 3 sebagai berikut. 
Tabel 3. Ringkasan Hasil Uji Homogenitas Kelompok Eksperimen dan Kelompok Kontrol

\begin{tabular}{cccc}
\hline Kelompok Data Hasil Belajar & $\mathbf{F}_{\text {hitung }}$ & $\mathbf{F}_{\text {tabel }}$ & Status \\
\hline $\begin{array}{c}\text { Eksperimen } \\
\text { Kontrol }\end{array}$ & 1,83 & 2,16 & Homogen \\
\hline
\end{tabular}

Dari Table di atas diketahui $F_{\text {hitung }}$ hasil belajar IPA siswa kelompok eksperimen dan kontrol adalah 1,83. Sedangkan $\mathrm{F}_{\text {tabel }}$ dengan $\mathrm{db}_{\text {pembilang }}=25-1=24, \mathrm{db}_{\text {penyebut }}=20-1=19$ dan taraf signifikansi $5 \%$ adalah2,16. Hal ini berarti $F_{\text {hitung }}<F_{\text {tabel }}$ sehingga varians data hasil belajar IPA siswa kelompok eksperimen dan kontrol adalah homogen.

Kemudian melakukan uji hipotesis yang pertama yaitu, "terdapat pengaruh secara efektif implementasi model pembelajaran Children Learning In Science (CLIS) terhadap hasil belajar IPA siswa kelas V SD Gugus X Kecamatan Kintamani Kabupaten Bangli Tahun Pelajaran 2017/2018". Dan diperoleh hasil ES = 1,84 ermasuk kedalam kriteria efektivitas tinggi. Hasil tersebut menyatakan bahwa terdapat pengaruh secara efektif implementasi model pembelajaran Children Learning In Science (CLIS) terhadap hasil belajar IPA Siswa kelas V SD di Gugus X Kecamatan Kintamani Kabupaten Bangli tahun pelajaran 2017/2018.

Selanjutnya uji hipotesis yang kedua menggunakan Uji ANAVA-A Satu jalur dengan kreteria $\mathrm{H}_{0}$ ditolak jika $\mathrm{F}_{\text {antar }}>\mathrm{F}_{\text {tabel }}$ pada tarap signifikan $5 \%$. Didapatkan $\mathrm{JK}_{\text {tot }}=1381,91, \mathrm{JK}_{\text {antar }}$ $=3379,49, \mathrm{JK}_{\text {dal }}=5792,65, \mathrm{RJK}_{\text {antar }}=3379,49, \quad R J K_{\text {dal }}=134,701$ dan $F_{\text {hit }}=25,08$ yang dibandingkan dengan $F_{\text {tabel. }}$ Untuk lebih jelasnya dapat disajian pada ringkasan Uji ANAVA pada Tabel 4 sebagai berikut.

Tabel 4. Ringkasan Hasil Uji Hipotesis Menggunakan Uji ANAVA

\begin{tabular}{|c|c|c|c|c|c|c|}
\hline $\begin{array}{l}\text { Sumber } \\
\text { Varian }\end{array}$ & JK & $\mathrm{db}$ & RJK & $F_{h}$ & $\begin{array}{l}F_{\text {tab }} \\
5 \%\end{array}$ & Keputusan \\
\hline Antar & 3379,49 & 1 & 3379,49 & 25,08 & 4,0566 & Signifikan \\
\hline Dalam & 5792,16 & 43 & 134,701 & - & & \\
\hline Total & 9171,65 & 44 & & - & & \\
\hline
\end{tabular}

Berdasarkan analisis data di atas ditemukan bahwa ; $F_{\text {hantar }}=25,08$ dan $F_{\text {tabel }}$ pada taraf signifikan $5 \%$ dengan db 43 adalah 4,0566. Ini berati $F_{\text {antar }}>F_{\text {tabel }}$ jadi $H_{0}$ ditolak. Dengan demikian terdapat perbedaan hasil belajar IPA siswa yang mengikuti pembelajaran dengan menerapkan model pembelajaran Children Learning In Science (CLIS) dan siswa yang mengukuti pembelajaran dengan menerapkan model pembelajaran konvensional pada siswa kelas V SD di Gugus X Kecamatan Kintamani Kabupaten Bangli tahun pelajaran 2017/2018.

Berdasarkan uji hipotesis yang dilakukan dapat disiimpulkan bahwa terdapat pengaruh secara signifikan model pembelajaran Children Learning In Science (CLIS) terhadap hasil belajar IPA siswa kelas V SD di Gugus X Kecamatan Kintamani Kabupaten Bangli tahun pelajaran 2017/2018.

Pembahasan hasil-hasil penelitian dan pengujian hipótesis ini menyangkut tentang hasil belajar IPA pada kelompok siswa yang mengikuti pembelajaran dengan menggunakan model pembelajaranChildren Learning In Science (CLIS)pada kelompok eksperimen dan siswa yang mengikuti pembelajaran dengan menggunakan pembelajaran konvensional pada kelompok kontrol. Dalam penelitian ini menunjukan bahwa terdapat pengaruh yang berbeda pada hasil belajar IPA siswa .

Berdasarkan pembahasan tentang pengaruh secara evektif implementasi model Children Learning In Science (CLIS) terhadap Hasil belajar IPA siswa kelas V SD di Gugus X Kecamatan Kintamani Kabupaten Bangli Tahun Pelajaran 2017/1018. Mendapatkan hasil análisis data hasil belajar IPA yang menggunakan uji t-burning memperoleh $t_{\text {hitung }}=9,20$. Hasil tersebut harus dikonsultasikan dengan kriteria tingkat keefektifan dengan rumus efektivitas size (ES) dan memperoleh hasil ES = 1,84 yang termasuk ke dalam kriteria efektivitas tinggi. sehingga dapat disimpulkan terdapat pengaruh secara efektif implementasi model pembelajaran Children Learning In Science (CLIS) terhadap hasil belajar IPA siswa kelas V SD di Gugus X Kecamatan Kintamani Kabupaten Bangli tahun pelajaran 2017/2018. Dan sejalan dengan penelitian yang dilakukan oleh Wardani (2017) yang berjudul "Efektifitas model pembelajaran Clis Berbantuan Media Slide Powerpoint Terhadap Hasil Belajar IPA" yang menyatakan bahwa ada pengeruh secara efektivitas penerapan model pembelajaran CLIS berbantuan media powerpoint terhadap hasil belajar IPA siswa kelas V SDN Pulerejo 
Kecamatan Pilangkenceng. Selanjutnya penelitian yang dilakukan oleh Budiarto (2014) yang menyatakan bahwa penerapan model CLIS terbukti efektif terhadap motivasi dan hasil belajar pada mata pelajaran IPA siswa. Dan menurut Rismi (2017) menyatakan bahwa model Talking Stick efektif terhadap hasil belajar matematika siswa kelas IV SD NegeriKarangsumber 01 Kabupaten Pati yang dilihat dari nilai rata-rata hasil belajar siswa sesudah mengggunakan model Talking Stick $(71,7)$ lebih tinggi daripada nilai rata-rata hasil belajar sebelum menggunakan model Talking Stick $(58,8)$.

Berdasarkan pembahasan tentang terdapat Perbedaan hasil belajar siswa siswa yang mengikuti pembelajaran dengan menerapkan model pembelajaran Children Learning In Science (CLIS) pada kelompok eksperimen dan siswa yang mengikuti pembelajaran dengan menerapkan pembelajaran konvensional pada kelompok kontrol,hal ini dapat dilihat dari hasil uji-ANAVA-A.

Secara deskriptif, hasil belajar IPA siswa kelompok Eksperimen lebih Tinggi di bandingkan dengan siswa kelompok Kontrol. Tinjauan ini di dasarkan pada rata-rata skor dan kecenderungan skor yang diperoleh pada kedua kelompok. Rata-rata hasil belajar IPA pada kelompok Eksperimen adalah 74,88, sedangkan rata-rata skor hasil belajar pada kelompok kontrol adalah 57,4 . Hal ini sudah terlihat bahawa rata-rata hasil belajar kelompok eksperimen lebih tinggi dari rata-rata hasil belajar pada kelompok kontrol.

Berdasarkan nalisis menggunakan uji-ANAVA-A, di peroleh $F_{\text {hantar }}=25,08$ dan $F_{\text {tabel }}$ pada taraf signifikan $5 \%$ dengan db 2:43 adalah 4,0566. Ini beratiF $F_{\text {antar }}>\mathrm{F}_{\text {tabel }}$ jadi $\mathrm{H}_{0}$ ditolak. Dengan demikian terdapat perbedaan hasil belajar IPA siswa yang mengikuti pembelajaran dengan menerapkan model Children Learning In Science (CLIS) pada kelompok eksperimen dan siswa yang mengikuti pembelajaran dengan menerapkan model pembelajaran konvensional pada kelompok kontrol kelas V SD di Gugus X Kecamatan Kintamani Kabupaten Bangli tahun pelajaran 2017/2018.

Temuan dari perbedaan hasil belajar IPA siswa yang dibelajarkan dengan model pembelajaran Children Learning In Science (CLIS) dan siswa yang dibelajarkan dengan model pembelajaran konvensional dapat dilihat dari langkah-langkah model pembelajarannya, dimana model pembelajaran Children Learning In Science (CLIS) mampu membangkitkan minat belajar siswa dan memancing siswa untuk mengemukakan pendapatnya dalam proses pembelajaran. Model ini mampu memancing siswa untuk mengemukakan gagasan siswa dalam kegiatan praktikum sehingga proses pembelajarannya menyenangkan. Model pembelajaran Children Learning In Science (CLIS) adalah model pembelajaran yang memiliki 5 tahapan yaitu, (1)orientasimerupakan upaya untuk memusatkan perhatian siswa, misalnya dengan menyebutkan dan mempertontonkan suatu peristiwa yang terjadi dalam kehidupan sehari-hari, yang berkaitan dengan topik yang dipelajari, (2)pemunculan gagasan merupakan upaya untuk memunculkan konsepsi awal siswa. Misalnya dengan cara meminta siswa menuliskan apa saja yang telah diketahui tentang topik pembicaraan, atau dengan menjawab beberapa pertanyaan uraian terbuka. Bagi guru tahapan ini merupakan upaya eksplorasi pengetahuan siswa. Oleh karena itu, tahapan ini juga dilakukan melalui wawancara informal, (3)penyusunan ulang gagasan merupakan upaya untuk memperjelas dan mengungkapkan gagasan awal siswa tentang suatu topik secara umum, misalnya dengan cara mendiskusikan jawaban siswa pada langkah kedua (pemunculan gagasan) dalam kelompok kecil, kemudian salah satu perwakilan kelompok menyampaikan hasil diskusi tersebut pada seluruh kelas. Pada tahap pembuktian ke situasi konflik siswa diberi kesempatan untuk mencari pengertian ilmiah yang sedang dipelajari di dalam buku teks.Selanjutnya siswa mencari beberapa perbedaan antara konsepsi awal mereka dengan konsepsi ilmiahyang ada dalam buku teks atau hasil pengamatan terhadap kegiatan yang dilakukan. Siswa diberi kesempatan untuk melakukan percobaan dengan observasi, kemudian mendiskusikannya dengan kelompoknya, (4)penerapan gagasan merupakan tahapan diminta siswa menjawab pertanyaan yang disusun untuk menerapkan konsep ilmiah yang telah dikembangkan siswa melalui percobaan/observasi ke dalam situasi baru, (5)pemantapan gagasan merupakan tahapan dimana konsepsi yang telah diperoleh siswa perlu diberi umpan balik oleh guru untuk memperkuat konsep ilmiah tersebut. Dengan demikian diharapkan siswa yang konsepsi awaknya tidak konsisten dengan konsep ilmiah sadar akan mengubah konsepsi awalnya menjadi konsep ilmiah.

Berdasarkan fase-fase model pembelajaran Children Learning In Science (CLIS) yang dilakukan saat penelitian, terlihat bahwa guru dalam pembelajaran memposisikan diri sebagai mediator dan fasilitator. Siswa diarahkan untuk melakukan kegiatan pembelajaran sesuai dengan fase-fase yang ada dalam model pembelajaran Children Learning In Science (CLIS) sehingga siswa dapat aktif dalam mengembangkan pengetahuannya sendiri terutama dalam 
mengemukakan gagasannya serta dapat berinteraksi secara positif dengan temannya melalui kegiatan praktikum. Hal tersebut sejalan dengan pendapat Wardana (2016), " Pengaruh Model Pembelajaran Children Learning In Science (CLIS) Terhadap Hasil Belajar IPA Kelas IV SD di Gugus VI Kecamatan Sawan" ModelChildren Learning In Science (CLIS)merupakan model pembelajaran yangberusaha mengembangkan ide ataugagasan siswa tentang suatu masalah tertentu dalam pembelajaran sertamerekonstruksi ide atau gagasanberdasarkan hasil pengamatan atau percobaan dan mampu membangkitkan minat belajar IPA siswa.Begitu pula menurut Dewi (2014) berjudul "Pengaruh Model Pembelajaran CLIS Terhadap Pemahaman Konsep IPA Siswa Kelas V SD di Gugus VII Kecamatan Sawan" temuan penelitian juga menunjukkanbahwa siswa sudah mampumengembangkan konsep awal yangdimilikinya menjadi sebuah konsep yangilmiah baik melalui kegiatan pengamatanmaupun percobaan yang dilakukan selama proses pembelajaran sehingga siswa mampu mengikuti pembelajaran dengan baik.

Berbeda halnya dalam pembelajaran dengan pembelajaran konvensional yang memiliki ciri pembelajaran berpusat pada guru yang menyebabkan siswa kurang aktif dalam pembelajaran dan hanaya bisa mendengar penjelasan guru. Model pembelajaran konvensional adalah pembelajaran yang biasa digunakan oleh guru dalam proses belajar mengajar yang sifatnya masih sangat umum dan belum inovatif, guru cenderung hanya menggunakan metode ceramah. Dalam pembelajaran konvensional yang menjadi pusat pembelajaran adalah guru, sedangkan siswa hanya menjadi pendengar dalam mengikuti pelajaran, serta kurangnya mengaitkan proses pembelajaran dengan kehidupan sehari-hari sehingga pembelajaran menjadi kurang bermakna. Hal inilah yang menyebabkan terjadinya proses pembelajaran menjadi kurang kondusif yang menyebabkan siswa cepat bosan dalam proses pembelajaran. Hal ini sejalan dengan pendapat Menurut Rasana (2009:20), menyatakan bahwa "Penyampaian materi dalam pembelajaran konvensional tersebut lebih banyak dilakukan melalui ceramah, tanya jawab, dan penugasan yang berlangsung secara terus menerus. Guru tetap berperan sebagai sumber informasi". Dan menurut Dewi (2014) "model konvensional,proses pembelajaran didominasi oleh guruyang lebih banyak diwarnai dengan transferinformasi dari guru kepada siswa". Begitu pula menurut Desi (2014) yang berjudul "Pengaruh Model Pembelajaran CLIS Berbantuan Media Grafis Berpengaruh Terhadap Hasil Belajar IPA Siswa Kelas V SD di Gugus Srikandi Denpasar Timur" menyatakan bahwa penerapan modelpembelajaran CLIS ini dapat membantu siswa agar mampu mencapai hasil belajaryang lebih baik.

Pembelajaran koncensional adalah pembelajaran yang hanya berpusat pada guru, siswa hanya sebagai pendengar karena guru hanya menyampaikan informasi melalui metode ceramah sehingga pembelajaran tidak berangsung kondusif.

Berdasarkan pemaparan diatas, dapat dinyatakan bahwa terdapat perbedaan hasil belajar IPA siswa yang mengikuti pembelajaran dengan menerapkan model Children Learning In Science (CLIS) dan siswa yang mengikuti pembelajaran dengan menerapkan model pembelajaran konvensional siswa kelas V SD di Gugus X Kecamatan Kintamani Kabupaten Bangli tahun pelajaran 2017/2018.

Berdasarkan pemaparan di atas, dapat disimpulkan bahwa terdapat pengaruh secara signifikan model pembelajaran Children Learning In Science (CLIS) terhadap hasil belajar IPA siswa kelas V SD di Gugus X Kecamatan Kintamani Kabupaten Bangli tahun pelajaran 2017/2018.

\section{Simpulan dan Saran}

Berdasarkan hasil pengujian hipotesis dan pembahasan, maka simpulan dari penelitian ini adalah sebagai berikut: 1) Terdapat Pengaruh secara efektif Implementasi model pembelajaran Children Learning In Science (CLIS) terhadap hasil belajar IPA siswa Kelas V SD di Gugus X Kecamatan Kintamani Dari hasil uji-t dapat diketahui bahwa nilai $t_{\text {hitung }}=9,20$. Hasil tersebut harus di konsultasikan dengan kriteria tingkat keefektifan dengan hasil $E S=1,84$ yang termasuk kriteria efektivitas tinggi sehingga dapat disimpulkan bahwa terdapat pengaruh secara efektif implementasi model pembelajaran Children Learning In Science (CLIS) terhadap hasil belajar IPA siswa kelas V SD di Gugus X Kecamatan Kintamani Kabupaten Bangli tahun pelajaran 2017/2018. 2) Terdapat perbedaan hasil belajar IPA siswa yang mengikuti pembelajaran dengan menerapkan model pembelajaran Children Learning In Science (CLIS) dan siswa yang mengikuti pembelajaran dengan menerapkan model pembelajaran Konvensional pada siswa kelas V SD di Gugus X Kecamatan Kintamani Kabupaten Bangli 
tahun pelajaran 2017/2018. Hasil analisis menunjukan nilai $F_{\text {hantar }}=25,08$ dan $F_{\text {tabel }}$ pada taraf signifikan $5 \%$ dengan db 2:43 adalah 4,0566. Ini berarti $F_{\text {hantar }}>F_{\text {tabel }}$ jadi $\mathrm{H}_{0}$ ditolak. Dengan demikian terdapat perbedaan hasil belajar IPA siswa yang mengikuti pembelajaran dengan menerapkan model Children Learning In Science (CLIS) dan siswa yang mengikuti pembelajaran dengan menerapkan model pembelajaran konvensional siswa kelas V SD di Gugus X Kecamatan Kintamani Kabupaten Bangli tahun pelajaran 2017/2018. Berdasarkan pemaparan, dapat disimpulkan bahwa terdapat pengaruh secara signifikan model pembelajaran Children Learning In Science (CLIS) terhadap hasil belajar IPA siswa kelas V SD di Gugus X Kecamatan Kintamani Kabupaten Bangli tahun pelajaran 2017/2018.

Berdasarkan penelitian tersebut disarankan kepada (1) siswa, guru, kepala sekolah agar hasil penelitian ini dapat menjadi motivasi agar guru mau menerapkan model-model pembelajaran di sekolah dan Kepada peneliti lain agar hasil penelitian ini dapat digunakan sebagai acuan kepustakaan untuk melakukan penelitian dalam variabel yang sama ataupun pada variabel yang berbeda.

\section{Daftar Pustaka}

Budiarto Fariz, dkk. (2014). "Keefektifan Model Pembelajaran CLIS (Children Learning In Science) Terhadap Motivasi dan Hasil Belajar IPA". Jurusan Pendidikan Guru Sekolah Dasar, FIP Universitas Negeri Malang. Jurnal Of ElementaryEducation 4.

Darmawati, Ni Pt. A., dkk (2013). "Pengaruh Model Pembelajaran Children Learning In Science Berbantuan Metode Talking Stick Terhadap Sikap IImiah dan Penguasaan Konsep IPA Kelas V". Jurusan Pendidikan Guru Sekolah Dasar, FIP Universitas Pendidikan Ganesha.e-Journal Mimbar PGSD Universitas Pendidikan Ganesha.

Ganesha, U. P. (n.d.). "Pengaruh Model Pembelajaran Children Learning In Science (CLIS) Terhadap Hasil Belajar IPA Kelas IV SD di Gugus VI Kecamatan Sawan".

Hamalik, Oemar. 2012. Kurikulum dan Pembelajaran. Jakarta: PT Bumi Aksara.

Ismai, Ali. 2017. Penerapan Model Pembelajaran Children Learning In Science (CLIS) Berbantuan Multimedia untuk Meningkatkan Keterampilan Proses Sains Siswa SMA Pada Pokok Bahasan Fluida. JIPFRI: Jurnal Inovasi Pendidikan Fisika dan Riset IImiah Vol. 1 No. 2 Hal. 83 - 87. Tersedia Pada: https://journal.stkipnurulhuda.ac.id/index.php/JIPFRI/article/view/114.

Koyan, I. Wayan. 2012. Statistik Pendidikan Teknik Analisis Data Kuantitatif .Singaraja: Universitas Pendidikan Ganeha Pers.

Lasmawan, I Wayan. 2013. Telaah Kurikulum. Singaraja: Surya Grafika.

Luh, N., Susanti, D., dkk. (2014). "Model Pembelajaran CLIS Berbantuan Media GrafisBerpengaruh Terhadap Hasil Belajar IPA Siswa Kelas V SD Gugus Srikandi Denpasar Timur". Jurusan Pendidikan Guru Sekolah Dasar, FIP Universitas Pendidikan Ganesha.e-Journal Mimbar PGSD Universitas Pendidikan Ganesha.

Nurani, Lilis Endah. 2017. Pengaruh Model Pembelajaran Children Learning In Science (CLIS) dengan Pemanfaatan Lingkungan Sebagai Sumber Belajar terhadap Kemampuan Mendeskripsikan Bagian Bunga dan Fungsinya pada Siswa Kelas IV SDN Gayam Kecamatan Mojoroto Kota Kediri Tahun Ajaran 2016/2017. Simki-Pedagogia Vol. 1 No. 2 Hal. 1-12. Tersedia Pada: http://simki.unpkediri.ac.id/mahasiswa/file_artikel/2017/27fd3066a855681d9a7bd4ebcf59 a97d.pdf.

Rasana, I. Dewa. PutuRaka. 2009. Laporan Sabbatical Leave Model-Model Pembelajaran.Singaraja: Undiksha. 
Rifai, Moh, dkk. (2017). "Efektivitas Model Pembelajaran CLIS Berbantuan Media Powerpoint Terhadap Hasil Belajar IPA". Fakultas Keguruan dan IImu Pendidikan, Universitas PGRI Madiun.

Samatowa, Usman. 2010.Pembelajaran IPA di Sekolah Dasar. Jakarta: PT. Indeks.

Susanto, Ahmad. 2013. TeoriBelajardanPembelajaran di SekolahDasar. Jakarta: Kencana.

Vidayanti Rismi., dkk (2017). "Keefektifan Model Talking Stick Terhadap Hasil Belajar Matematika Siswa Kelas IV". Jurusan Pemdas Mahakam, FIP Universitas PGRI Semarang.

Wardani, Riska Fajar Ayu Kusuma, Moh. Rifai, Titin Kuntum Mandalawati. 2017. Efektivitas Model Pembelajaran Clis Berbantuan Media Slide Powerpoint Terhadap Hasil Belajar IPA. Premiere Educandum Jurnal Pendidikan Dsar dan Pembelajaran Vol. 7 No. 2 Hal. 104 - 114. Tersedia Pada: http://e-journal.unipma.ac.id/index.php/PE. 